\title{
Literature as a source for history The case of the Repen Ripangi (1886)
}

\author{
WILLEM VAN DER MOLEN
}

\begin{abstract}
ABSTRAK
Teks sejarah berbeda dengan teks sastra. Teks sejarah menceritakan apa yang benar-benar terjadi di masa lalu sementara teks sastra tidaklah demikian. Oleh karena itu, sejarawan sering menghindari penggunaan teks sastra dalam penelitian mereka. Saya berargumen bahwa teks sastra dapat menambahkan dimensi lain pada wawasan sejarah, yang tidak ditemukan dalam dokumen sejarah. Analisis puisi Jawa berjudul Repen Ripangi dari abad kesembilan belas menunjukkan bahwa teks ini, selain memberikan laporan yang sangat menarik tentang pendamaian ideologis seorang reformis muslim, juga membuka jalan bagi penulisnya dalam menyuarakan kritiknya terhadap kekuasaan kolonial Belanda.

KATA KUNCI

Javanese literature (sastra jawa), nineteenth century (abad kesembilan belas), repen, Ahmad Rifa'i, Islam, reformism (reformisme), Snouck Hurgronje.
\end{abstract}

Kyai Ahmad Rifa'i or Ahmad Ripangi or Muhammad Ripangi ( $\pm 1786-1875)$ was a religious teacher who lived in Central Java, in the area of Pekalongan. But he was much more than just a religious teacher, he was also a reformist. Furthermore, he founded a religious movement, made a distinct contribution to Javanese literary history, and became the subject of Javanese literature himself. It is in this latter quality that I want to discuss him in this article.

The work of Javanese literature that has Ahmad Rifa' $i$ as its subject is a poem with the name Repen Ripangi. This poem is interesting for two reasons: for what it has to say about the historical figure of Ahmad Rifa' $i$, and for the use made of it as a source of historical information about him.

A major event in Kyai Ahmad Rifa'i's life took place in 1859. In that year he was arrested and exiled to the island of Ambon. These severe steps were taken by the Netherlands-Indies government because Ahmad Rifa' $\mathrm{i}$ was considered a threat to peace in Java; there had been repeated complaints about him from

WILLEM VAN DER MOLEN is librarian of the Koninklijk Instituut voor Taal-, Land- en Volkenkunde/KITLV (Royal Netherlands Institute of Southeast Asian and Caribbean Studies) in Leiden; he also teaches at Leiden University (Javanese and Old Javanese literature). Together with Prof. Edwin Wieringa of Universität Köln, Germany, he is preparing a new edition of the Repen Ripangi. 
the local religious and wordly authorities. Sartono Kartodirdjo distinguishes two categories of religious leaders in the colonial setting, reformists and conservatives. He further observes that this religious division coincided with a political division between opponents of the colonial regime and those who at least passively accepted it (Sartono Kartodirdjo 1973: 125). The Repen Ripangi was written by a bupati and an assistant wedono, members of Sartono Kartodirdjo's second category and as such the opponents of Ahmad Rifa'i who fell into the first category. Their creative work shows the negative appreciation for Haji Rifa'i one would expect in such a case.

A remarkable difference between the facts known from the history books and history as told in the poem is that in the poem the affair does not conclude with a sentence and exile but with a public debate and repentance. Public debates are a well-known topos in traditional Javanese literature, the most famous case being that of Seh Siti Jenar. Note that, different from the heroes of other texts, Ahmad Rifa'i in the Repen Ripangi is defeated and as a consequence has to give up his teaching.

As for the topos as such, this difference between the history of the historians and that of the literati raises the wider question of what the poet's view on the matter was and how he conveyed that view. This is one of the two questions I want to address.

A second reason why the Repen Ripangi is of interest is because of the way the poem has been or at least may seem to have been employed in historical research. Long after the upheaval around Kyai Ahmad Rifa'i had subdued and long after the main character himself had died, around the turn of the century, the colonial authorities became alarmed again by the circulation of his works in Javanese society. The matter was investigated by C. Snouck Hurgronje, at the time official advisor of the Netherlands-Indies government on colonial affairs. Snouck discussed the ideas of Ahmad Rifa'i on the basis of an analysis of his works, adding information on the nature and effect of his activities on the basis of a source or sources he did not reveal (see the letters written by Snouck Hurgronje to various colonial officials between 1895 and 1904 as published in Gobée and Adriaanse 1965: 1930-1943). It is my impresssion that the Repen Ripangi may have played a role here. This raises the second question I want to discuss: what are the clues connecting the Repen Ripangi to the historical research of Snouck Hurgronje and what actually is the historical information offered by it?

Before turning to the Repen Ripangi and Snouck Hurgronje I shall first say a few things about the life and work of Ahmad Rifa'i. My sources are Steenbrink 1984 and Djamil [2001], unless stated otherwise.

\section{KyAi AHMAD RIFA'I}

After a stay of eight years in Mecca in the 1830s, early in the 1840s Ahmad Rifa'i established a pesantren in the village of Kalisalak in Central Java. This was near the village of Kendal, in the same area where he originally came from. In his teaching he stressed the necessity of reform: he wanted to restore 
Islam to its original and pure form, purged from local accretions such as wayang performances or gamelan music, meetings without segregation of the sexes, women appearing in public without covering their heads, etcetera. The Javanese leaders, both wordly and religious, according to Kyai Ahmad Rifa'i were characterized by ungodly behaviour and a lack of the right knowledge, and hence treated their subjects with injustice and lead them astray by their false interpretations of the kitabs. Only ulamas of proper conduct (called alim adil, 'learned and righteous', by Ahmad Rifa'i) who did not pervert the contents of the kitabs and taught in plain Javanese should be obeyed (Gobée and Adriaanse 1965: 1933).

Ahmad Rifa'i spread his message also in writing. In addition to a great number of smaller, pamphlet-like works of an exhortative or polemic nature he wrote several major works, such as the Husn al-matalib or the Abyan alhawaij, to mention two (they all carry Arabic titles, although all are written in Javanese). These major works are concerned with dogma, law, and mysticism. It becomes clear from their contents that Ahmad Rifa'i did not try to break new ground but adapted the lessons of authoritative Arabic kitabs to a Javanesespeaking audience. He himself underlined this intermediate character of his works by referring to them as tarajumah, 'translation' (Gobée and Adriaanse 1965: 1936).

Reading was made even more attractive by applying poetry. A peculiar feature was that Kyai Ahmad Rifa' $i$ did not use the traditional form of Javanese poetry, macapat, as one might have expected, but nazam, an Arabic, syair-like form in which each line ends in the same vowel. See the following example, a stanza taken from the Abyan al-hawaij:

Maka syari'at tan hakikat becampurane

$i k u$ dadi suwung ora nana isine

utawi hakikat tan syari'at tinemune

$i k u$ rusak tan nana kamunfaatane

(Djamil [2001]: 174)

Therefore the law if not integrated with true reality

becomes empty, it has no content.

And true reality if not blended with the law

disintegrates and has no use.

In 1859 Ahmad Rifa'i's activities were abruptly halted. In that year he was arrested, sentenced, and exiled to Ambon. He never returned to Java but stayed in Ambon until his death.

What had paved the way to Ambon according to Steenbrink was Ahmad Rifa'i's criticism of Javanese political and religious leadership. His criteria for lawful, truly Muslim leaders - meeting the conditions of alim and adil referred to above - branded all those who had not studied under him as non-Muslim and this viewpoint, stated loud and clear, must have caused a great deal of annoyance in the attacked circles (Steenbrink 1984: 105). Ahmad Rifa'i even had declared invalid their Friday services or the marriage contracts signed 
under their supervision (he actively disturbed some Friday services; see Sartono Kartodirdjo 1973: 124).

It was not the first time that charges were brought against Ahmad Rifa'i. Repeated attempts to silence him had already been made before 1859. Until then these had been unsuccessful, among other things, because Ahmad Rifa' $\mathrm{i}$ had not been examined. However, in 1859 the Governor General decided that enough evidence had been gathered to remove Ahmad Rifa'i.

In fact, evidence in 1859 was as meager as it had been before. This is clear from the archival material in Jakarta. Steenbrink, who in 1984 was the first to closely examine the Ahmad Rifa'i file, explains the decision of 1859 from the conservative stand of the new Governor General (Steenbrink 1984: 101).

Summarizing the above, one might say that the picture offered by historiography shows a theological dispute left undecided by rhetorical means and a colonial government which acts as the custodian of peace, impartial but not tolerant ad infinitum.

Which view does the Repen Ripangi offer?

\section{REPEN RIPANGI}

Most interestingly, Ahmad Rifa'i became the subject of a literary work in Javanese, the Repen Ripangi. A repen is a lyrical song in macapat meter (according to the dictionary; it is, however, not mentioned in the handbooks of Javanese literature). The text was first published in 1886 in an edition in Javanese characters by Jayasubrata. It was published again by Hadisutjipto and Hadisuprapta in 1981 in Latin characters, together with a translation into Indonesian.

The authorship of the Repen Ripangi was a combined affair, or so it appears from the prose introduction that precedes the poem (in the 1886 edition):

Punika repĕn anyariyosakĕn kaji Pinang pangulu Batang Pakalongan, pabĕn bab prakawis agami, klayan kaji Ripangi dhusun Kalisalak, kabupaten Batang rĕsidhensi Pakalongan. Ingkang kagungan babonipun kangjĕng rahaden adipati panji Suryakusuma, bupati pensiun ing nagari Samarang.

Sarehning pitěmbunganipun kathah ingkang kirang prayogi dados kadamĕl lĕrĕs dening raden panji Jayasubrata, wadana ondĕrsĕtan ing Magĕtan.

This is a poem, relating the story of haji Pinang, panghulu in Batang, Pekalongan, and his debate about religious matters with haji Ripangi of the village of Kalisalak, in the regency of Batang and the residency of Pekalongan.

The original text belonged to the honourable raden adipati panji Suryakusuma, retired regent of Semarang. As it was not very well expressed, it was corrected by raden panji Jayasubrata, assistant wedana of Magetan.

We learn from this introduction that the authorship involved one Suryakusuma, retired bupati of Semarang, and one Jayasubrata who was assistant wedono in Magetan (in the residence of Madiun). Suryakusuma was the actual author while Jayasubrata acted as his editor (but we do not know how far he went in editing the text). We can assume that this introduction was added to the text 
on the basis of information given in the first two stanzas of canto 1 . There we find the same information, moreover it is also stated that Jayasubrata turned the original version into macapat. So Suryakusuma had written a prose text, and Jayasubrata acted not merely as the editor but was involved as the poet. The present whereabouts of the prose text are unknown. To what extent the poem is a faithful rendering of the original is therefore impossible to decide. It stands to reason that poetical requirements will have influenced the text in one way or another in its transition from prose to poetry. The specific requirements of a repen have not yet been the subject of research.

The first stanza of the first canto informs us in the traditional way, by means of a chronogram, about the date of the Repen Ripangi: catur janma mĕnggaleng rat, 'four people are the commanders of the world', which means 1814 AJ or $1884 \mathrm{AD}$ (the edition of 1981 equates 1814 AJ with $1892 \mathrm{AD}$, mistakenly treating the Javanese year as a year of the Saka calendar; see Hadisutjipto and Hadisuprapta 1981: 9).

The Repen Ripangi counts sixty-two pages in the edition of Hadisutjipto and Hadisuprapta. The story is spread over seven cantos. In the first three cantos we read about Ahmad Rifa'i's successful activities in Kalisalak: instructing his pupils, being invited to preach in the mosques of surrounding villages where many people come to listen to him and offer him gifts. Meanwhile the penghulu of Pekalongan is trying to find out more about Ahmad Rifa'i since he has heard some alarming rumors. When he realizes the purport of Haji Rifa'i's teaching he reports to the bupati of Pekalongan, his superior. The bupati first asks for more information, also from Ahmad Rifa'i himself (who writes him a letter), and then decides to hold a public debate in which Ahmad Rifa' $i$ and the religious officials of the area will have the opportunity to present and discuss their views.

The public debate takes place in cantos 4-6. It is held in Pekalongan; the bupati acts as the chairman. When all the officials invited for the occasion are seated Ahmad Rifa'i's letter is first read aloud; then Ahmad Rifa'i is called to the meeting. The debate takes the form of a discussion between two participants, Ahmad Rifa'i and the penghulu of Batang, Haji Pinang. There are two sessions because Ahmad Rifa'i asks for a break.

At the beginning of the first session Haji Pinang straight-away raises the problem of the validity or invalidity of the Friday services, one of the core points of Kyai Rifa' i's teaching. On what grounds, so he wants to know, does Ahmad Rifa'i declare services other than the ones led by himself or his pupils as invalid? Haji Rifa'i answers that the idea of validity or invalidity was not invented by him but rests on authoritative kitabs in Arabic. A vehement discussion develops, in which none of the participants gives in to the other. In the heat of the discussion arguments are replaced by abusive language. In the end, after Haji Pinang repeatedly asked what Ahmad Rifa'i's Arabic sources were, Ahmad Rifa'i admitted that he could not produce them because he did not bring them to the meeting and had forgotten their titles. He asked the chairman for a break in order to be able to collect the works Haji Pinang 
is asking for. The break is granted.

The second session, a few days later, is a disastrous repetition of the first. The audience is reminded why Ahmad Rifa' $i$ was given a break and why he is now expected to give the required account. Haji Pinang pins him down on the three central points of his teaching, (1) the Friday services, (2) the marriage ceremonies, and (3) the number of believers required to be present at the Friday services, all revolving around the question of validity, and mercilessly pursues him for an answer on the question where he got these ideas from. But Ahmad Rifa'i again cannot answer, he still did not bring the required books because he could not find them. Haji Pinang makes mincemeat of him. The bupati decides that Ahmad Rifa'i has lost the debate and orders him to publicly renounce his doctrines.

A meal concludes the meeting, after which everybody goes home.

In canto 7 we are told how the controleur, the local representative of the colonial government, reports the debate to his superior, the resident, or rather to that gentleman's right-hand man, the secretary, as the resident happens to be on a tour. The controleur is able to do so since he had attended the debate for quite some time (in canto 6). The secretary, in the absence of the resident, writes a letter to the bupati ordering him to arrest Ahmad Rifa'i. After the resident has returned the bupati reports to him about what has happened. The resident praises the bupati for the way he has handled the problem.

\title{
POETIC EMBELLISHMENTS
}

Although the ins and outs of the repen still have to be studied, it is clear that the Repen Ripangi is not a factual report on events that happened around the middle of the nineteenth century. The Repen Ripangi is a piece of literature. The rules of poetry, wording, the order of the scenes, additional stories, the commentaries of the omniscient narrator and other elements all add to its character as a work of literary art. A few examples may serve to illustrate how Raden Panji Jayasubrata has accomplished his task.

The topos of the public debate as a literary device has already been mentioned. Another example is the set-up of the opening scene of the Repen Ripangi, which is borrowed from the wayang. The reader finds himself at the court of the ruler of Pekalongan (for example, the bupati), who is described in terms of a righteous prince whose realm prospers under his rule and who is assisted by a faithful patih or prime minister, exactly as a wayang play has it (Canto 1.4):

\author{
Kang jinĕjĕr carita ing ngarsi \\ duk nalika panjĕnĕnganira \\ kangjĕng raden tumĕnggunge \\ Wiryadinagara nung \\ Pakalongan prajanireki \\ pasisir tanah Jawa \\ de papatihipun \\ dyan bei Mĕrtanagara
}


budidarma mumpuni sarjana niti

prajanya gӗmah arja

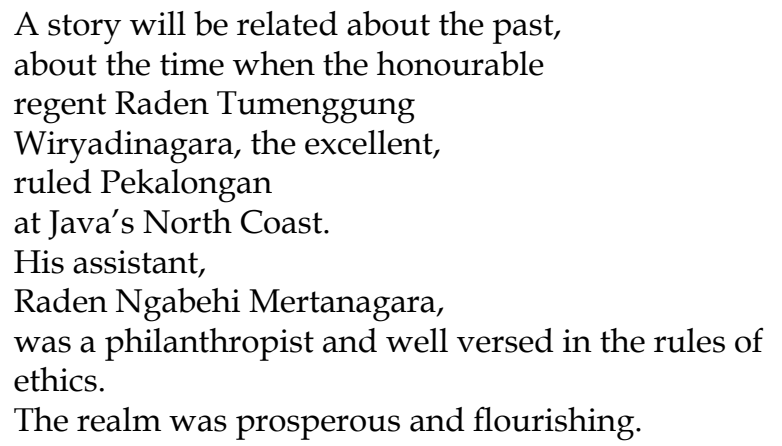

The story is set in motion when the penghulu appears in the following lines and reports the rumors about Ahmad Rifa' $i$. This reminds one of the next scene of a wayang play where the king receives a prominent servant reporting on some disturbance or other, threatening the order of the kingdom and challenging the king to do something to save his kingdom.

The court of the counter kingdom of the wayang play in the Repen Ripangi is represented by the pesantren of Ahmad Rifa' $i$, where the master happens to be addressing his pupils. He too has a kind of patih, for which role the author has created the figure of Jariyah, a converted village head of Suranata, and now the confidant of Ahmad Rifa'i.

The experienced reader will not fail to perceive the implications of such a wayang-like opening in terms of a distinction between good and evil parties. Ahmad Rifa' $i$ is on the wrong side and therefore is doomed to be defeated.

Further research will no doubt bring more similarities with the shadow play and also with other literary genres to light, in addition to characteristic features of the repen itself.

The Repen Ripangi is a lively told text written in simple language. The insertion of all sorts of details and observations, often of a humorous but also of a human or philosophic or other nature intertwined in the main story make the text a very entertaining one.

Take for example Jariyah, the converted village head who leads a busy life as the right-hand man of Ahmad Rifa' $i$, acting as the intermediate through whom people approach the Kyai and representing him if necessary, for example, with the authorities. He is evidently an important man. Mrs. Jariyah, however, rather down-to-earth, does not like her husband to be away from home alone so often; who knows what will happen (Canto 2.30):

Yen kakang marěk kiyai

aturĕna sĕmbah ingwang

lawan pamĕkasku maneh

ywa suwe neng Kalisalak

bangĕt sumĕlang ingwang

bok sira dipundhut mantu

kakang paran polah ingwang 
If you go to the kyai,

give him my regards

and furthermore I implore you

not to stay in Kalisalak too long.

I am very worried

that you may become someone's son-in-law,

and what should I do then?

She loves him and, she adds realistically, they have to keep a household going (jĕr anakmu akeh kuwe, 'after all, you have many children'. Canto 2.32).

Or take this insight in human nature. Ahmad Rifa'i has no problem in attracting followers because as long as things go well, they come in great numbers. But when his defense falters the audience is merciless (Canto 5.20):

\section{Suka kang sami tumingal arame gantya nyĕnggaki \\ Ripangi sěmu kasoran}

The audience enjoyed itself, cheering loudly time after time. Ripangi seemed to loose.

The favor of the masses is fleeting indeed.

Another literary device, for example, the particular order of successive scenes, helps to convey the contents of Ahmad Rifa'i's teachings. Bit by bit, through the mouth of different characters we learn in well-balanced quantities what these teachings are. The opening scene of the Repen Ripangi, for example, introduces the penghulu of Pekalongan reporting to the bupati on vague but alarming rumours about one Ahmad Rifa'i (Canto 1.6. The object of the penghulu's greeting in line 1 is the bupati. Ahmad Rifa' $i$ is called Muhammad Ripangi here):

Ki pangulu wau manganjali

dhuh pukulun kawula miyarsa

ing Batang inggih wartose

Kalisalak kang dhusun

wontĕn kaji amulang ngelmi

Muh $\square$ amad Ripangi nama

punika misuwur

anyampah sagung ngulama

ngelminipun tan wontĕn ingkang prayogi

sĕdaya sami galat

The penghulu greeted him first with a sembah:

'O my lord, I have heard

the news from Batang

that in the village of Kalisalak

a haji is teaching a doctrine.

His name is Muhammad Ripangi. 
He is well-known

for rejecting all ulamas,

their teachings are all wrong,

all of them are mistaken.'

These lines bring the reader straight to the heart of the matter: look, here is a man who says we have done it all wrong! They state in a few words what the Repen Ripangi is about. That is all they do, no more. But then, that is enough to arouse curiosity. The reader has to go on, indeed wants to go on in order to find out what this is all about. Therefore, in the next lines (Canto 1.7) the bupati orders the penghulu to find more information about this new doctrine. Then, however, this line of the story is discontinued for a time; the reader has to hold up his curiosity. Instead the attention switches to the pesantren of Kyai Ahmad Rifa'i. The teaching he is engaged in is the kind of basics used for beginners, precisely the topics which won him his fame among the masses: the invalidity of the Friday services and marriage ceremonies of the ulamas and penghulus, and why these are not valid (Canto 1.8-12).

In this way, going from the spectacular to the hidden, from the surface to the underlying ideas, broadening the knowledge of the reader step by step, while keeping his attention by changing the scenes of instruction, the author arrives at a fairly complete overview of Ahmad Rifa' i's doctrines.

At the same time the author takes care to prevent the reader from getting the impression as if Haji Rifa' $i$ 's views would be correct. That his views cannot be correct is made clear in several ways on more than one occasion. In the scene of Ahmad Rifa' $i$ and his pupils just cited this is done by embedding the instruction of the kyai in an outburst of arrogance. At the beginning (Canto 1.8-9):

Kabeh padha pirsakna nak murid mami yen ingsun iki iya

mĕne dadi khalifah jĕng Nabi

My dear pupils, you should know that I personally

am now the deputy of the Prophet

At the end (Canto 1.12):

Mĕngko iki padha rungokĕna

kabeh murid ingsun kiye

ing tanah Jawa iku

iya mangsa ing dina iki

kabeh para ngulama

liyane jĕnĕng sun

tan ana kang adil nyata

amung ingsun sampurna sayĕkti adil 
Therefore, listen

all of my pupils.

In Java

at the present time

among all the ulamas

there is no one who is truly righteous

apart from me.

Only I am perfect and truly righteous.

This serves to ensure that the reader sees the narrator's point, in asides and through the mouths and thoughts of his characters, which explains the incompatibility of such self-glorifications with being a true Muslim. It follows that one should not listen to Haji Rifa'i.

It is always tempting to caricature one's opponent and fight that caricature rather than the opponent himself. Something of the sort is happening here. Ahmad Rifa' $i$ is cited as calling himself sampurna adil, 'perfect and righteous'. In the eyes of Ahmad Rifa'i's adversaries it may have amounted to the same thing as alim adil, 'learned and righteous', but it is not the same. It made Ahmad Rifa'i an easy target.

The disapproving view on Ahmad Rifa'i expressed in these and similar passages is supported by other means. The silent division between good and evil parties implied in the opening scenes of the text is one such means. Outward appearance, especially physical features and gestures, and the social and psychological interpretation given to it - a traditional science in Java called wirasat - is another. One spectator, himself a penghulu, while listening intently to the discussion closely observes the looks of the discussants. His conclusion is that Ahmad Rifa'i could not possibly be a prominent scholar; his build and complexion rule that out (he calls them sĕpi, 'empty, lacking [something]'. Canto 5.38-40).

\section{A DIFFERENT OPINION?}

It is clear that the author of the Repen Ripangi is not an admirer of Ahmad Rifa'i. However, this does not automatically mean that the author takes side with the colonial government. It seems as if the Repen Ripangi is claiming room for a third, independent position. Sartono Kartodirdjo's division into two categories is too simple.

A comparison between the archival material about Ahmad Rifa'i and the Repen Ripangi brings some interesting differences and similarities to light concerning the way the affair was dealt with by the authorities. I begin with the similarities. A look at the material in the National Archive in Jakarta as cited by Steenbrink shows that all layers of officialdom were involved, from the local wedono through the bupati in Batang and resident in Pekalongan to the Governor General in Batavia. The Governor General was involved because he was the one who could decide on banishment. The request for banishment was directed to him by the resident of Pekalongan, who acted on request of the bupati of Batang. The bupati of Batang had been approached by the wedono 
of Kalisalak (Steenbrink 1984: 101-102). The track of the request reflects the composite structure of the colonial administration.

We find a similar track in the Repen Ripangi. Of course the Governor General is not involved because exile is not under discussion. The highest level on the Dutch side is that of the resident of Pekalongan. He is informed by his secretary who had been briefed by the controleur. The controleur had been filled in, I suppose, by the bupati of Pekalongan, when he dropped by at the debate between Ahmad Rifa' $i$ and Haji Pinang, towards the end of the second session. The bupati of Pekalongan organized the debate because he was alarmed by his penghulu, who had the news from the people at Kalisalak.

The close parallel between the historical tradition of the archive and the literary tradition of the Repen Ripangi regarding the passage of information through the official hierarchy is yet another literary device, used in the Repen Ripangi to indicate its character of what in the case of a novel would be called an historical novel - let us say in this case of an historical repen. This indication is strengthened by the use of real names: the characters in the story carry the names of persons who really existed in the nineteenth century: the Dutch Van de Poel and Vijzelaar, the resident and secretary in the Repen Ripangi, really were the resident and secretary in Pekalongan in the 1850s. The same holds for the Javanese officials like Raden Arya Wiryadinegara, bupati of Pekalongan, Ki Arya Puspadiningrat, bupati of Batang, and others. See the Almanak en naamregister for the relevant years.

Ideally, for the benefit of colonial society, all functionaries on all administrative levels worked smoothly together. This is what the analogy between the two types of representation, historical and literary, seems to underline: in the real world of the historian and in the fictional world of literature the administrative wheelwork turned very well. It is therefore striking that the details are worked out differently. According to the archival material all stages of the official hierarchy are completely passed through, the information flows from the lowest Javanese to the highest Dutch level, where the final decision is taken after a critical review of the received information. In the Repen Ripangi, however, the Dutch officials cannot send on the information, let alone take the final decision, because they are not informed: they are unaware that something is going on, and when they become aware the decision has already been taken. Even this is not registered with them because then they start taking decisions as if nothing had been done yet. The Repen Ripangi sees a lack of feedback (Canto 7.11):

Kagyat dupi myarsa atur

wau tuwan sekrĕtaris

tan mawi catur pariksa

tumĕnggung tan den timbali

sigra akarya nuwala

ki tumĕnggung den prentahi

The secretary was shocked when he heard these words [for example, the report of the controleur]. 
Without further mentioning an investigation, and without summoning the Tumenggung, he immediately wrote a letter with an order for the Tumenggung.

The bupati (referred to by his title of tumenggung here) is ordered to have Kyai Ahmad Rifa'i confined in his house, while a ban is imposed on his teaching (Canto 7.12-13).

The secretary compares unfavourably with the bupati. We get to know the latter as a highly responsible man who does not skate on thin ice. When he hears about Ahmad Rifa'i for the first time, through the report of the penghulu, he says carefully (Canto 1.7):

Den tumĕnggung angandika aris
yen mangkono sira anĕrangna
apa kang dadi mangsude
mungguh ngelmune iku
gone mulang mring murid-murid.

The Raden Tumenggung spoke quietly:

'If that is the case, please find out

what the intentions are

of his doctrine

which he teaches to his pupils.'

What the bupati is doing here is in fact checking the information of the penghulu. The matter seems serious enough, certainly if what the penghulu says is true. Therefore, the bupati does not take chances. We find the same attitude when he instructs the penghulu to organize the public debate: if Ahmad Rifa' $i$ is wrong he should renounce his teachings, if he is right everybody should become his pupil, so he spurs the penghulu (Canto 3.25). He repeats this once more in front of the gathered people when he opens the debate (Canto 4.1920). Please note that listening to both sides was a weak point of the Dutch authorities also according to the documentation in the archives (see the end of the second section of this article).

One might wonder why in the Repen Ripangi the case is closed with a public renouncement and not with banishment. Is it because renouncement offers the possibility of reconciliation? It is less extreme anyway than banishment. It might also be more prudent in view of the hoped-for effect the living demonstration of changed insights might have on the followers. The Repen Ripangi leaves it to the reader to interpret this particular aspect.

The differences which arise from the above comparison show that the Javanese section of the colonial administration according to the literary presentation of the events was not as passive in its acceptance of Dutch colonial rule as Sartono Kartodirdjo wants us to believe. The Dutch action against Ahmad Rifa'i could not be prevented but it was by no means prompted by Javanese cooperation. On the contrary, the Repen Ripangi flatly suggests it would have better if the Dutch had stayed out. 
SNOUCK HURGRONJE

C. Snouck Hurgronje wrote about Ahmad Rifa'i more than forty years after the event, around 1900. At that time the memory of the affair and the man who gave his name to it was still alive, enough to make the colonial officials worry when they found that the works of Ahmad Rifa'i were still circulating among the people. Snouck Hurgronje gave his advise in the form of three letters sent to three colonial officials, to the residents of Pekalongan and Kedu in 1895 and 1900, and to the Governor General in 1904. The letters were published in the Ambtelijke adviezen van C. Snouck Hurgronje (Gobée and Adriaanse 1965: 1930-1943).

The advise proper concentrated on the question whether measurements should be taken against the people on whom the works of Haji Rifa'i had been found. Snouck did not think so. His argument was that these works called to a stricter observance of the law, dismissing the established leaders (because they were distorting the truth) but which in no case called to rebellion against the colonial government; so there was nothing wrong with them. However, the latter may have been on the hidden agenda of the writer, Snouck added by way of a belated justification of Ahmad Rifa'i's exile.

Snouck based his advise on his analysis of the works of Ahmad Rifa'i available to him. The analysis constitutes the greater part of the letters. In between there are scattered remarks on Ahmad Rifa'i's activities and influence. Where did Snouck Hurgronje find this information? He does not mention his source or sources.

At the time nothing had been published on the Ahmad Rifa'i affair as far as I know. The only sources I can think of are the oral information of people who had been directly or indirectly involved, and two written sources, the archival material and the Repen Ripangi.

As far as oral information is concerned, besides eyewitnesses possibly met by Snouck Hurgronje, whom he does not mention, there is one person he does mention in the letter of 1895. This is the 'penghulu masjid' of Pekalongan. Snouck omits his name; he only writes that they met for a couple of hours in 1889 , so quite some time before he wrote his letter. What interested Snouck at that time was that while Ahmad Rifa'i drew most of his following from the common people there were nevertheless also members of the higher classes who agreed with his teachings, even though it was the higher classes that were attacked by Ahmad Rifa'i. As an example Snouck, in his letter of 1895, points to the penghulu of Pekalongan (Gobée and Adriaanse 1965: 1932). Whether he was a source for other information we do not hear, nor do we hear what his relation was with the penghulu of Pekalongan back in the 1850s.

Snouck Hurgronje remains silent about the documents from the archives. This may mean that he did not see them. One detail of Ahmad Rifa'i's life which might have interested him, which these documents could have provided him with, is Ahmad Rifa'i's stay of eight years in Mecca. See the text of the interrogation reproduced in Steenbrink 1984: 109-113. 
The Repen Ripangi was published in 1886 and therefore was available to Snouck Hurgronje when he wrote his letters from 1895 onwards. Is it possible that he used this text for the extra information? It seems an odd hypothesis but there are several striking similarities between the Repen Ripangi and Snouck Hurgronje's letters. Compare the following points:

1. Concrete information on Ahmad Rifa'i's life and activities is almost absent from the Repen Ripangi. In fact it is limited to the information that he had his headquarters in Kalisalak and that he was summoned to Pekalongan to take part in the public debate on the validity of his teaching. The latter may be true or not; it could also merely be a literary topos (which it is anyway). Snouck is equally sparing in this kind of information; as far as he does give this kind of information he mentions precisely the same two items. Ahmad Rifa'i's stay in Mecca is not discussed by the Repen Ripangi; neither is it by Snouck.

2. The Repen Ripangi states that it was mostly the common people, presented as the ignorant masses by the text, who were susceptible to Ahmad Rifa'i's influence. Snouck says exactly the same, qualifying his assertion with his remark about the sympathetic attitude among members of the higher classes, citing the penghulu of Pekalongan.

3. The Repen Ripangi distinguishes two categories of followers, Ahmad Rifa'i's pupils proper, who studied with him, and a wider circle of adherents who liked to listen to him on a less demanding basis. Snouck makes the same distinction.

While it is theoretically possible that these facts were fabricated by the authors independently or that they were common knowledge at the time, I think that especially the overall correspondence - what is mentioned by the Repen Ripangi is also mentioned by Snouck Hurgronje; what is not in the Repen Ripangi is also not in Snouck Hurgroje - is an argument in favour of my hypothesis that we are not talking about a chance resemblance but that Snouck Hurgronje was indebted to the Repen Ripangi.

One might object that the same information can also be found in a third source, namely Sartono Kartodirdjo's book on protest movements in rural Java of 1973. But as Sartono Kartodirdjo drew his information to a large extent literally from Snouck's letters, and therefore cannot be considered an independent source on Ahmad Rifa'I, this cannot count as an argument. Why Snouck Hurgronje did not mention the Repen Ripangi as his source-provided I am right - is not so easy to guess. Was it because taking refuge to a repen would not have impressed his readers as solid scholarship?

\section{CONCLUSION}

While offering information on the same subject, archival documentation and the Repen Ripangi appear to do so in quite different ways. The Repen Ripangi is a literary text and as such meets different requirements than a historical text. One of the most notable differences is of course its fictional, non-referential nature. It is because of this quality that literary texts have always been considered less 
fit as a source of historical research; the Repen Ripangi is no exception.

Leaving the theoretical aspect of the use of literary texts for historical research to the qualified scholars I have tried in this article to find out what it is the author of the Repen Ripangi wanted to say.

I found that the author in the first place wanted to warn against the teachings of Kyai Ahmad Rifa'i. This is clear on almost every page, where it is stated in so many words, and also by means of the many literary devices applied throughout the text, such as presentation, order, wording and many more.

A second message brought to light concerns colonial rule. The presence of the Dutch in Indonesia was of course not appreciated by many Indonesians, witness the many efforts to get rid of them by force. In addition to force, literature had a role to play. The historical events revoked in the Repen Ripangi are presented in such a way that the rule of the Dutch is marked as ill-informed, superfluous, and unfair. In 1886 such things could not be said in the press. Literature offered a proper outlet.

A side-effect of this outcome is that Sartono Kartodirdjo's two-fold division of religious leadership into reformists and conservatives, coinciding with the political division of opponents and collaborators (or those who at least did not offer active resistance), is not invalidated but needs adjustment: the collaborating faction was not as submissive as it seemed to be. Only it expressed its opposition not through action but through writing.

The second subject tackled in this article is the question whether Snouck Hurgronje, writing on Ahmad Rifa'i, may have had recourse to the Repen Ripangi when looking for historical particulars. Certain similarities between his texts and the Repen Ripangi might point in that direction. Although today the use of literature for historical research is no longer as sectarian as it used to be - there is in fact a large body of theoretical writings on the subject - in the field of Indonesian studies the practitioners are still few and far between. It is a pleasant surprise therefore that as early as 1886 Snouck Hurgronje already set an example. The way he did it - taking information of the Repen Ripangi at face value and without mentioning his source - is now no longer recommended. But if literary texts are available it would be to the detriment of the historian not to use them.

\section{BIBLIOGRAPHY}

Almanak en naamregister. 1855. Almanak en naamregister van Nederlandsch-Indië voor 1855. Batavia: Landsdrukkerij.

Almanak en naamregister. 1859. Almanak en naamregister van Nederlandsch-Indië voor 1859. Batavia: Landsdrukkerij.

Djamil, Abdul. [2001]. Perlawanan kyai desa; Pemikiran dan gerakan Islam kh. Ahmad Rifa'i Kalisalak. [Yogyakarta:] LKiS.

Gobée, E. and C. Adriaanse (eds). 1965. Ambtelijke adviezen van C. Snouck Hurgronje 1889-1936. Vol.3.'s-Gravenhage: Nijhoff. (Rijksgeschiedkundige Publicatiën, Kleine Serie 35). 
Hadisutjipto, Sudibjo Z.; and T.W.K. Hadisuprapta (eds). 1981. Serat Cebolek. Jakarta: Proyek Penerbitan Buku Sastra Indonesia dan Daerah, Departemen Pendidikan dan Kebudayaan.

Jayasubrata (ed.). 1886. Punika Serat Cabolek, anyariyosaken ing nalika keraton Kartasura, panjenenganipun kangjeng susuhunan Sumareng Nglawean, ing wektu mas ketib Anem Kudus paben kalayan kaji Amad Mutamakim, dhusun Cabolek bawah negari Tuban, bab prakawis ngelmu tekad. Katurun kangjeng raden adipati panji Suryakusuma, bupati pensiun ing negari Samawis. Semawis: Van Dorp.

Kartodirdjo, Sartono. 1973. Protest movements in rural Java; A study of agrarian unrest in the 19th and early 20th centuries. Singapore: Oxford University Press.

Steenbrink, K.A. 1984. Beberapa aspek tentang Islam di Indonesia abad ke-19. Jakarta: Bulan Bintang. 